\title{
Hypoglycemic, antidyslipidemic, and antioxidant activities of methanol extract of Struchium sparganophora leaves in alloxan- induced oxidative stress-mediated diabetes
} in rats

\author{
A. M. Adeosun ${ }^{1,2^{*}}$ (D, F. O. Asejeje ${ }^{3}$, O. M. Ighodaro' ${ }^{1}$ B. A. Oluwole ${ }^{1}$ and O. A. Akinloye ${ }^{2}$
}

\begin{abstract}
Background: Diabetes mellitus is clinically underlined by hyperglycemia and dyslipidemia. In view of this, the current study assessed the glycemic and lipidemic control potentials of methanol extract of Sruchium sparganophora leaves (SPA) in the alloxan-induced diabetic model using male Wistar rats. Experimental diabetes was induced through a single intraperitoneal injection of $120 \mathrm{mg} / \mathrm{kg}$ freshly prepared alloxan. Thirty-six rats were randomly assigned into six groups of normoglycemic control, untreated diabetic group, and diabetic treated with (i) metformin (12 mg), (ii) metformin $12 \mathrm{mg}+$ SPA $300 \mathrm{mg} / \mathrm{kg}$, (iii) SPA $300 \mathrm{mg} / \mathrm{kg}$, and (iv) SPA $600 \mathrm{mg} / \mathrm{kg}$ per os twice at 9.00 and $18.00 \mathrm{~h}$ daily for 10 days. Fasting blood glucose (FBG) level and markers of dyslipidemia, and oxidative stress markers were determined.
\end{abstract}

Results: SPA at selected doses decreased fasting blood glucose which was significantly $(p<0.05)$ raised by alloxan. Increase in plasma total cholesterol (TC), low-density lipoprotein cholesterol (LDL-C), and triglyceride (TG) concentrations and decrease in HDL-cholesterol (HDL-C) concentration $(p<0.05)$ caused by alloxan were significantly moderated by SPA at selected doses. Glutathione-s-transferase (GST), superoxide dismutase (SOD), and catalase (CAT) activities reduced by alloxan $(p<0.05)$ in both the liver and pancreas were reversed by SPA 300 and 600 , and its combination with metformin. Decreased reduced glutathione (GSH) concentration in alloxan diabetic rats was also reversed by the extract, while the level of malondialdehyde (MDA) exacerbated by alloxan $(p<0.05)$ in the tissues was decreased by the extracts.

Conclusion: Struchium sparganophora possesses considerable antihyperglycemic, antidyslipidemic, and antioxidant potentials without compromising organ functionality.

Keywords: Alloxan, Diabetes, Dyslipidemia, Oxidative stress

\footnotetext{
* Correspondence: adeosun.amuhammad@|cu.edu.ng

'Department of Biochemistry, Lead City University, Ibadan, Nigeria

2Department of Biochemistry, College of Biosciences, Federal University of

Agriculture, Abeokuta, Nigeria

Full list of author information is available at the end of the article
}

\section{Springer Open}

(c) The Author(s). 2020 Open Access This article is licensed under a Creative Commons Attribution 4.0 International License, which permits use, sharing, adaptation, distribution and reproduction in any medium or format, as long as you give appropriate credit to the original author(s) and the source, provide a link to the Creative Commons licence, and indicate if changes were made. The images or other third party material in this article are included in the article's Creative Commons licence, unless indicated otherwise in a credit line to the material. If material is not included in the article's Creative Commons licence and your intended use is not permitted by statutory regulation or exceeds the permitted use, you will need to obtain permission directly from the copyright holder. To view a copy of this licence, visit http://creativecommons.org/licenses/by/4.0/. 


\section{Background}

Diabetes mellitus (DM) is a disease associated with fat, carbohydrate, and protein metabolic disorders due to defects in insulin secretion, insulin action (sensitivity), or both [1]. Patients with diabetes have a high incidence of cardiovascular disease especially hypertension, atherosclerosis, cardiomyopathy, and microvascular damage. In fact, it is the most comorbid condition reported in patients with hypertension [2]. Besides hyperglycemia, several other comorbidities such as dyslipidemia (imbalance in lipid homeostasis) and free radical generation are involved in the development of diabetes-related cardiovascular complications which are the major cause of morbidity and death.

Struchium sparganophora (Linn.) Ktze. belongs to the Asteraceae family. It is a fibrous culinary shrub that grows in the tropical Africa. The leaf is commonly called water bitter leaf and locally called "ewuro odo" among the Yoruba tribe of South Western Nigeria. It is a water plant consumed as a leafy vegetable in soup preparations among the rural occupants in Nigeria. It is used ethnomedicinally for the management of diabetes mellitus, malaria, measles, headache, and gonorrhea [3-6]. The nutritional, antioxidant, antimicrobial, and antimalarial activities of leaves of S. sparganophora have been documented [6-8]. Sesquiterpene lactone has been isolated from the plant [5]. In vitro study on $\alpha$-amylase and $\alpha$ glucosidase inhibitory activities suggested the leaves could possess hypoglycemic activity [9]. Although there has been increasing information on the nutritional and medicinal significance of the plant in question, there is little available information on the possible pharmacological mechanisms of actions of the plant to substantiate the antidiabetic property ascribed to it from ethnomedicinal and in vitro studies. This study, therefore, sought to determine the hypoglycemic potential and possible pharmacology mechanisms of actions of methanol extract of S. sparganophora leaves in alloxaninduced diabetic rats

\section{Methods}

\section{Chemical and drugs}

Alloxan was obtained from Sigma-Aldrich (Germany) and metformin $\mathrm{HCl}$ from Shuangwei Pharm. Co. Ltd (China). Other reagents used for this study were of analytical grade.

\section{Plant sample preparation}

Struchium sparganophora was obtained from Badeku farm in Ibadan and was authenticated and deposited in herbarium with voucher number UIH 22655 by Mr. Donatus, a botanist at the University of Ibadan, Ibadan, Nigeria. The leaves were separated from the stems, dried, and pulverized at room temperature. Three hundred grams of the powdered leaves was weighed and extracted with $2.4 \mathrm{~L}$ of absolute methanol, centrifuged at $2000 \mathrm{rpm}$ for $5 \mathrm{~min}$; the supernatant was collected; and the solvent was evaporated at $40{ }^{\circ} \mathrm{C}$ on a rotary evaporator to obtain the crude methanol extract of the leaves.

\section{Assay for drug active content}

Standard metformin $\mathrm{HCl}$ active content was assayed using the standard procedure before use [10].

\section{Experimental design and animal care}

Thirty-six male rats weighing 145-153 g were obtained from the Department of Veterinary Medicine, the University of Ibadan, transported to the animal house, Department of Biochemistry, Lead City University, Ibadan. The rats were handled humanely and managed according to the protocol of the Animal Research Ethics Committee of Lead City Ethical Review Board (LCU/ERB). The rats were kept in plastic cages in 12-h light and dark conditions. They were acclimatized for 2 weeks prior to the study and served vital feed and water throughout the study.

Using stratified randomization based on bodyweight and blood glucose level, the rats were divided into six groups ( $n=6 /$ group). Group A was the control (no treatment), and diabetes was induced in groups B-F by intraperitoneal injection of alloxan $(120 \mathrm{mg} / \mathrm{kg})$. Rats that showed fasting blood glucose levels of above 220 $\mathrm{mg} / \mathrm{dL}$ were taken to be diabetic. The animal groups were assigned treatment as follows: $\mathrm{B}$ - no treatment (ALO); $\mathrm{C}-$ metformin as standard, $12 \mathrm{mg} / \mathrm{kg}$ (MET); and $\mathrm{D}-$ metformin $12 \mathrm{mg} / \mathrm{kg}+\mathrm{SPA} 300 \mathrm{mg} / \mathrm{kg}(\mathrm{MET}+\mathrm{SPA}$ 300), SPA $300 \mathrm{mg} / \mathrm{kg}$ (SPA 300), and SPA $600 \mathrm{mg} / \mathrm{kg}$ extract (SPA 600). The rats were treated twice daily at $9.00 \mathrm{~h}$ and $18.00 \mathrm{~h}$ for 10 days. ACCU-CHECK glucometer with strips was used to check blood glucose concentration. Bodyweight of the animals was determined before administration of alloxan (day 0) and after treatment (day 10). Fasting blood glucose concentration was checked before administration of alloxan, $48 \mathrm{~h}$ after administration of alloxan (before treatment), and on the last day of the treatment. On the 10th day of treatment, the rats were fasted overnight $(8 \mathrm{~h})$. Blood was collected by ocular puncture into plain and lithium heparinized bottle; the blood samples were centrifuged at $3000 \mathrm{rpm}$ for $15 \mathrm{~min}$ to obtain the serum and plasma, respectively. The rats were euthanized with ether, and their liver, kidney, and pancreas were excised, washed (in $1.15 \% \mathrm{KCl}$ ), and homogenized in $10 \mathrm{mM}$ phosphate buffer $\mathrm{pH} 7.4$ (1: 4 ), and centrifuged at $12,500 \mathrm{rpm}$ to obtain the postmitochondria fractions

\section{Serum and plasma biochemical analyses}

In the serum, alanine aminotransferase and aspartate aminotransferase were assayed using the method 


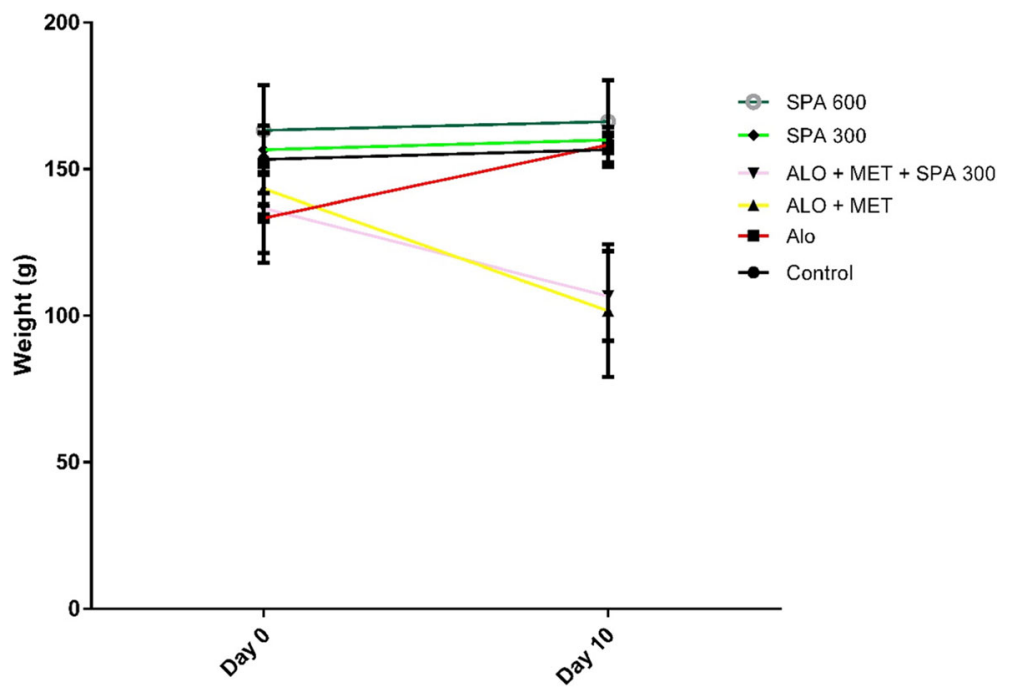

Fig. 1 Effect of methanol extract of S. sparganophora leaves on the bodyweight of alloxan-induced hyperglycemic rats. Results were expressed as mean + standard deviation

described by Reitman and Frankel [11], and alkaline phosphatase was assayed with the method described by Englehardt et al. [12]. In the plasma, triglyceride was determined using the method of Fossati and Prencipe [13], HDL-C was determined with the method of LopezVirella et al. [14], and total cholesterol was determined using the method of Zollner and Kirsch [15]. LDL-C and VLDL-C were calculated from the obtained lipid parameters using the formula by Friedewald et al. [16]. Cholesterol ratio $(\mathrm{CR})$ was calculated with the formula:

$$
\text { Cholesterol ratio }=\frac{\mathrm{TC}}{\mathrm{HDL}-\mathrm{C}}
$$

Atherogenic index (AI) was calculated using the following formula:

$$
\mathrm{AI}=\frac{\mathrm{TC}-\mathrm{HDL}-\mathrm{C}}{\mathrm{HDL}-\mathrm{C}}
$$

\section{Tissue oxidative stress markers}

The following were determined in the postmitochondria fractions of the liver, kidney, and pancreas of the rats: total protein (TP) [17], lipid peroxidation (MDA) [18], reduced glutathione (GSH) [19], glutathione-s-transferase (GST) [20], superoxide dismutase activity (SOD) [21], and catalase activity (CAT) [22].

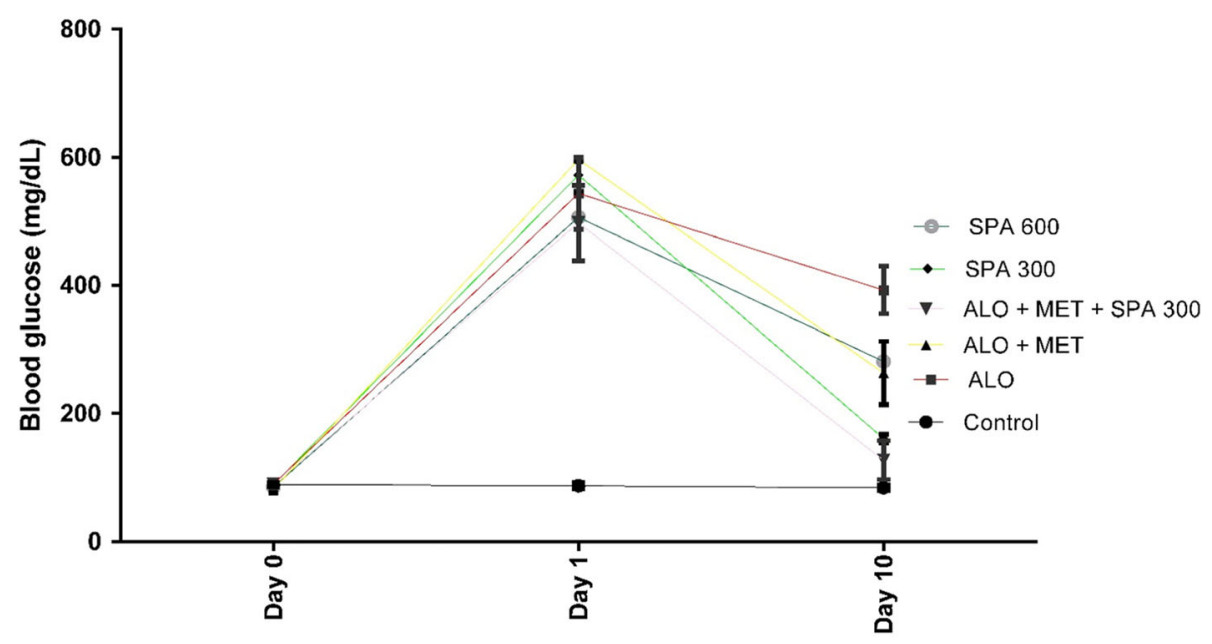

Fig. 2 Effect of methanol extract of S. sparganophora leaves on fasting blood glucose concentration of alloxan-induced hyperglycemic rats 
Table 1 Effect of methanol extract of S. sparganophora leaves on liver enzyme activities in alloxan-induced hyperglycemic rats

\begin{tabular}{llll}
\hline Groups & ALT (IU) & AST (IU) & ALP (IU) \\
\hline Control & $4.68 \pm 0.36$ & $17.67 \pm 0.21$ & $50.03 \pm 6.00$ \\
ALO & $7.52 \pm 0.67^{\mathrm{a}}$ & $20.29 \pm 0.11^{\mathrm{a}}$ & $68.93 \pm 1.47^{\mathrm{a}}$ \\
MET & $10.96 \pm 0.11^{\mathrm{a}, \mathrm{b}}$ & $18.66 \pm 0.52$ & $55.20 \pm 0.08^{\mathrm{b}}$ \\
MET + SPA 300 & $5.42 \pm 0.37^{\mathrm{b}, \mathrm{c}}$ & $14.07 \pm 1.08^{\mathrm{a}, \mathrm{b}, \mathrm{c}}$ & $49.98 \pm 2.29^{\mathrm{b}}$ \\
SPA 300 & $5.23 \pm 0.32^{\mathrm{b}, \mathrm{c}}$ & $15.71 \pm 0.05^{\mathrm{b}, \mathrm{c}}$ & $53.36 \pm 4.25^{\mathrm{b}}$ \\
SPA 600 & $5.56 \pm 0.47^{\mathrm{b}, \mathrm{c}}$ & $13.42+2.30^{\mathrm{a}, \mathrm{b}, \mathrm{c}}$ & $49.45 \pm 1.22^{\mathrm{b}}$
\end{tabular}

The results were expressed in mean \pm standard deviation

${ }^{\text {a }}$ Significant when compared to control at $p<0.05$

${ }^{\mathrm{b}}$ Significant when compared to ALO at $p<0.05$

'Significant when compared to ALO + MET at $p<0.05$

\section{Data analyses}

Analyses were performed using GraphPad Prism 6.05 (GraphPad Inc., USA). Parameters were presented as mean \pm standard deviation of animals in each group. Values in all groups were tested for differences with one-way analysis of variance coupled with Tukey's multiple comparisons test.

\section{Results}

Prior to treatment, the average weight of alloxan diabetic rats used was $147.78 \pm 11.63$, and $18 \%$ increase in bodyweight was observed in rats that were administered alloxan alone, while metformin and metformin supplemented with 300 $\mathrm{mg} / \mathrm{kg} \mathrm{BW}$ caused $29.4 \%$ and $22.1 \%$ decrease in bodyweight of the rats. The trend in the effect of SPA on the bodyweight of alloxan-induced diabetic rats can be found in Fig. 1.

Alloxan at $120 \mathrm{mg} / \mathrm{kg}$ BW produced the hyperglycemic conditions in the rats. This was effectively reversed by a combination of metformin with SPA 300. Considerable reductions of blood glucose were seen in rats treated with metformin alone, and extract at selected doses (Fig. 2).

Alloxan caused an increase in serum ALT and AST activities. ALT was further in the rats that were treated with metformin alone. The extract was able to reverse the effect of alloxan on serum ALT and AST activities (Table 1). Alloxan also increased the serum activity of ALP, and treatment with the extract (SPA) or when the low dose is combined with metformin reversed the effect of alloxan on serum ALP (see Table 1).

Intraperitoneal administration of $120 \mathrm{mg} / \mathrm{kg} \mathrm{BW}$ alloxan causes a marked increase in total cholesterol, and this effect was reversed $(p<0.05)$ by treatment with the plant extract alone or in combination with metformin. Serum HDL-cholesterol reduced in rats administered alloxan alone. The combination of low-dose extract and metformin markedly increases the HDL-cholesterol level. More information on the effect of S. sparganophora on the lipid profile of alloxan-induced diabetic rats can be found in Table 2 . Increased cardiac risk and atherogenic risk index were noted in rats administered alloxan alone when compared to the control and treatment groups (see Table 3).

Treatment with metformin markedly increased total protein concentration in the liver of the rats. More detail on total protein concentration in the liver, kidney, and pancreas can be found in Table 4. SPA effectively reversed $(p<0.05)$ increased the level of malondialdehyde caused by alloxan in the liver, kidney, and pancreas of the rats (Table 4$)$. This extract markedly increased $(p<$ 0.05 ) reduced glutathione concentration in the liver and pancreas of hyperglycemic rats better than metformin, though only SPA 600 increased level of glutathione in the kidney (Table 4).

SPA markedly increased catalase activity in the liver, kidney, and pancreas of alloxan diabetic rats. The extract also increased activities of SOD in the liver and pancreas, though kidney SOD activities were found to decrease in rats treated with the extract. In this finding, GST activity was markedly decreased by alloxan in the liver and kidney of the rats; meanwhile, SPA reverses the effect by increasing the activity in a manner comparable to metformin, though treatment with SPA and metformin does not normalize GST activity in alloxan diabetic rats. Further detail on antioxidant enzymes can be found in Table 5 .

\section{Discussion}

Green leafy vegetables are plants of medicinal values that have been used in the management of different diseases.

Table 2 Effect of methanol extract of S. sparganophora leaves on lipid profile of alloxan-induced hyperglycemic rats

\begin{tabular}{llllll}
\hline Groups & TC $(\mathrm{mg} / \mathrm{dL})$ & $\mathrm{HDL}-\mathrm{C}(\mathrm{mg} / \mathrm{dL})$ & $\mathrm{LDL}-\mathrm{C}(\mathrm{mg} / \mathrm{dL})$ & $\mathrm{TG}(\mathrm{mg} / \mathrm{dL})$ & $\mathrm{VLDL}-\mathrm{C}(\mathrm{mg} / \mathrm{dL})$ \\
\hline Control & $19.13 \pm 0.57$ & $7.14 \pm 0.41$ & $1.39 \pm 0.46$ & $49.25 \pm 7.40$ & $9.855 \pm 1.48$ \\
ALO & $21.72 \pm 0.69^{\mathrm{a}}$ & $3.27 \pm 0.42^{\mathrm{a}}$ & $3.29 \pm 0.45^{\mathrm{a}}$ & $75.99 \pm 4.30^{\mathrm{a}}$ & $15.40 \pm 0.56^{\mathrm{a}}$ \\
MET & $19.29 \pm 0.19^{\mathrm{b}}$ & $6.94 \pm 0.73^{\mathrm{b}}$ & $2.57 \pm 0.43$ & $46.34 \pm 3.32^{\mathrm{b}}$ & $9.265 \pm 0.66^{\mathrm{b}}$ \\
MET + SPA 300 & $18.75 \pm 0.69^{\mathrm{b}}$ & $6.52 \pm 0.39^{\mathrm{b}}$ & $1.69 \pm 0.81^{\mathrm{b}}$ & $53.95 \pm 4.40^{\mathrm{b}}$ & $10.29 \pm 0.37^{\mathrm{b}}$ \\
SPA 300 & $18.23 \pm 1.63^{\mathrm{b}}$ & $6.38 \pm 0.33^{\mathrm{b}}$ & $1.96 \pm 0.53^{\mathrm{b}}$ & $41.18 \pm 1.65^{\mathrm{b}}$ & $8.235 \pm 0.33^{\mathrm{b}}$ \\
SPA 600 & $17.29 \pm 1.17^{\mathrm{b}}$ & $6.22 \pm 0.49^{\mathrm{b}}$ & $2.13 \pm 0.63$ & $38.26 \pm 6.57^{\mathrm{b}}$ & $7.653 \pm 1.31^{\mathrm{a}, \mathrm{b}}$ \\
\hline
\end{tabular}

The results were expressed in mean \pm standard deviation

${ }^{a}$ Significant when compared to control at $p<0.05$

${ }^{\mathrm{b}}$ Significant when compared to ALO at $p<0.05$

'Significant when compared to ALO + MET at $p<0.05$ 
Table 3 Effect of methanol extract of S. sparganophora leaves on cardiovascular disease index in alloxan-induced diabetic rats

\begin{tabular}{lll}
\hline Groups & Cardiac risk index & Atherogenic risk index \\
\hline Control & 2.67 & 1.68 \\
ALO & $6.64^{\mathrm{a}}$ & $5.64^{\mathrm{a}}$ \\
MET & $2.78^{\mathrm{b}}$ & $1.78^{\mathrm{b}}$ \\
MET + SPA 300 & $2.88^{\mathrm{b}}$ & $1.87^{\mathrm{b}}$ \\
SPA 300 & $2.86^{\mathrm{b}}$ & $1.85^{\mathrm{b}}$ \\
SPA 600 & $2.78^{\mathrm{b}}$ & $1.78^{\mathrm{b}}$ \\
\hline
\end{tabular}

${ }^{\mathrm{a}}$ Significant when compared to control at $p<0.05$

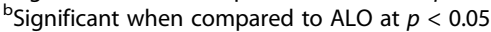

'Significant when compared to ALO + MET at $p<0.05$

This study evaluated the antihyperglycemic, antidyslipidemic, and antioxidant potentials of methanol extract of Struchium sparganophora leaves in the alloxan diabetic model. The ardent antihyperglycemic and antihyperlipidemic efficacies produced by this plant extract, especially when combined with metformin, revealed that the plant possesses phytoconstituent(s) with hypoglycemic efficacy or capable of being synergistic or potentiating the effect of metformin. The hypoglycemic efficacies of this plant involve bodyweight reduction. Increased bodyweight and dyslipidemia are comorbid and complications of diabetes mellitus. Consumption of vegetable-rich diets has been reported to serve a beneficial role in preventing obesity and diabetes mellitus and promoting health as they are rich sources of dietary fibers and phenolic antioxidants with low calories [23, 24]. Major features of dyslipidemia in diabetes mellitus are elevated plasma level of TC, LDL-C, and triglycerides, with decreased level of HDLC. There is limited glucose utilization by body cells, which call for the need for another source of energy; hence, there is increased secretion of fatty acids in adipose tissues which are converted in the hepatocytes to triglycerides and cholesterol then released into circulation. There is also increased VLDL-C, which accumulatively caused decreased HDL-C concentration.
In the current study, the irregular lipid homeostasis was observed in rats administered alloxan alone, and this finding corroborates with several other studies [25, 26]. This effect has resulted in increased cholesterol ration and atherogenic risk index. SPA at selected dosages seems to sufficiently mitigate dyslipidemia via reducing storage form of fat (triglycerides) and increasing HDL-C to an extent comparable to metformin. Treatment with SPA moderated LDL-C, VLDL-C, and total cholesterol level in the plasma of alloxan rats. Several other alcohol extracts of medicinal plants have been documented with antidyslipidemic effects in alloxan and another model of diabetes rats. Akinloye and Solanke [25] reported a marked reduction in serum triglyceride, total cholesterol, high-density lipoprotein, and low-density lipoprotein cholesterol in alloxan-induced hyperglycemic rats treated with Pigeon pea methanol extract. Sapium ellipticum leaf ethanol extract has been reported to maintain lipid homeostasis in streptozocin-induced diabetic rats [27].

In addition to the hypoglycemic effect and moderation of dyslipidemia, the leaf extract exhibited medicinal efficacies by reducing some markers of tissue injuries. SPA decreases plasma activities of ALT, AST, and ALP activities which were increased in alloxan diabetic rats in this study. Administration of alloxan could have resulted in leakage of these enzymes from the liver and some other tissues into circulation, indicating the injury of these tissues. The effect of SPA on liver enzyme markers is in agreement with several other studies on medicinal plant effects in diabetic rats $[27,28]$.

Administration of methanol extract of Struchium sparganophora leaves to alloxan diabetic rats moderated tissue oxidative stress markers in the selected tissues. Oxidative stress in the selected tissues, as seen in alloxan diabetes rats, occurs when superoxide dismutase, catalase, and glutathione systems (the endogenous antioxidant system) which effectively break down hydrogen peroxide and hydroperoxides to harmless molecules are

Table 4 Effect of methanol extract of S. sparganophora leaves on total protein, malondialdehyde, and reduced glutathione in alloxan-induced hyperglycemic rats

\begin{tabular}{|c|c|c|c|c|c|c|c|c|c|}
\hline \multirow[t]{2}{*}{ Group } & \multicolumn{3}{|l|}{ TP (mg/g tissue) } & \multicolumn{3}{|c|}{ MDA (nM MDA/mg protein tissue) } & \multicolumn{3}{|c|}{ GSH (nM GSH/mg protein tissue) } \\
\hline & Liver & Kidney & Panci & Liver & Kidney & Pancreas & Liver & Kidney & Pancreas \\
\hline ontrol & $33.06 \pm 2.11$ & $1 \pm 1.48$ & $4 \pm 0.89$ & $97 \pm 4.09$ & $45.25 \pm 3.73$ & $04 \pm 2.12$ & $32.26 \pm 2.14$ & $42.26 \pm 2.14$ & $3.01 \pm 0.23$ \\
\hline ALO & $48.60 \pm 9.39^{\mathrm{a}}$ & $36.59 \pm 2.08$ & $34.18 \pm 0.56^{\mathrm{a}}$ & $64.75 \pm 3.11$ & $75.68 \pm 6.11^{\mathrm{a}}$ & $40.14 \pm 6.01$ & $20.09 \pm 4.12^{\mathrm{a}}$ & $37.09 \pm 4.12$ & $2.05 \pm 0.07^{a}$ \\
\hline MET & $58.39 \pm 0.27^{a, b}$ & $35.44 \pm 0.50$ & $36.84 \pm 0.79^{a, b}$ & $23.53 \pm 0.40^{a, b}$ & $61.09 \pm 0.08^{\mathrm{a}, \mathrm{b}}$ & $49.30 \pm 0.25^{\mathrm{a}}$ & $26.95 \pm 1.75^{b}$ & $40.00 \pm 2.75$ & $2.77 \pm 0.04^{b}$ \\
\hline MET + SPA 300 & $39.91 \pm 2.68^{c}$ & $28.18 \pm 0.67^{a, b, c}$ & $39.41 \pm 0.83 b$ & $45.42 \pm 5.12^{\mathrm{a}, \mathrm{b}, \mathrm{c}}$ & $49.53 \pm 4.44^{b, c}$ & $24.67 \pm 0.18^{b}$ & $26.23 \pm 3.04^{a, b}$ & $41.23 \pm 3.04$ & $3.20 \pm 0.35^{b}$ \\
\hline SPA 300 & $31.08 \pm 1.15^{b, c}$ & $28.99 \pm 2.41^{a, b, c}$ & $41.21 \pm 1.07^{b, c}$ & $51.44 \pm 5.61^{a, b, c}$ & $44.15 \pm 9.25^{b, c}$ & $31.71 \pm 0.18^{c}$ & $29.30 \pm 3.70^{b}$ & $39.30 \pm 3.70$ & $2.85 \pm 0.22^{b}$ \\
\hline SPA 600 & $36.46 \pm 0.47^{b, c}$ & $31.19 \pm 1.89^{a, b, c}$ & $39.70 \pm 2.19^{b, c}$ & $52.93 \pm 2.49^{a, b, c}$ & $43.21 \pm 1.11^{\mathrm{b}, \mathrm{c}}$ & $39.27 \pm 0.94^{c}$ & $33.04 \pm 1.08^{c}$ & $43.04 \pm 1.08^{b}$ & $3.25 \pm 0.29^{b}$ \\
\hline
\end{tabular}


Table 5 Effect of methanol extract of S. sparganophora leaves on antioxidant enzymes in alloxan-induced hyperglycemic rats

\begin{tabular}{|c|c|c|c|c|c|c|c|c|c|}
\hline \multirow[t]{2}{*}{ Group } & \multicolumn{3}{|c|}{$\begin{array}{l}\mathrm{CAT}\left(\mu \mathrm{mol} \mathrm{H}_{2} \mathrm{O}_{2} \text { consumed/min/mg }\right. \\
\text { protein) }\end{array}$} & \multicolumn{3}{|c|}{$\mathrm{SOD}$ (nmol/min/mg protein) } & \multicolumn{3}{|c|}{ GST (nmol CDNB-GSH/min/mg protein) } \\
\hline & Liver & Kidney & Pancreas & Liver & Kidney & Pancreas & Liver & Kidney & Pancreas \\
\hline Control & $23.46 \pm 1.30$ & $18.09 \pm 1.30$ & $7.64 \pm 0.65$ & $43.95 \pm 2.06$ & $33.95 \pm 2.06$ & $20.47 \pm 0.98$ & $43.66 \pm 3.30$ & $34.82 \pm 3.30$ & $30.82 \pm 3.30$ \\
\hline ALO & $17.31+0.97^{\mathrm{a}}$ & $15.31 \pm 0.97^{a}$ & $5.90 \pm 0.70^{\mathrm{a}}$ & $27.87 \pm 3.22^{\mathrm{a}}$ & $30.87 \pm 3.22$ & $13.67 \pm 1.2^{\mathrm{a}}$ & $27.44 \pm 2.10^{\mathrm{a}}$ & $31.44 \pm 4.10$ & $17.44 \pm 2.10^{\mathrm{a}}$ \\
\hline MET & $21.95 \pm 1.76^{\mathrm{b}}$ & $15.95 \pm 1.76$ & $6.00 \pm 0.65^{\mathrm{a}}$ & $33.59 \pm 2.11^{\mathrm{a}}$ & $30.59 \pm 2.11$ & $18.67 \pm 2.57^{b}$ & $26.97 \pm 3.40^{\mathrm{a}}$ & $35.07 \pm 3.40$ & $25.07 \pm 3.40^{\mathrm{a}, \mathrm{b}}$ \\
\hline $\mathrm{MET}+\mathrm{SPA} 300$ & $22.32 \pm 0.55^{b}$ & $18.11 \pm 0.55^{b}$ & $6.41 \pm 0.21^{\mathrm{a}}$ & $33.21 \pm 3.41^{\mathrm{a}}$ & $31.21 \pm 3.41$ & $17.98 \pm 1.01^{b}$ & $32.05 \pm 0.95^{a, b}$ & $37.00 \pm 0.95^{b}$ & $27.00 \pm 0.95^{b}$ \\
\hline SPA 300 & $21.04 \pm 0.40^{\mathrm{a}, \mathrm{b}}$ & $17.60 \pm 1.40$ & $6.35 \pm 0.22^{a}$ & $27.10 \pm 3.90^{\mathrm{a}}$ & $29.10 \pm 3.90$ & $18.03 \pm 0.22^{b}$ & $29.03 \pm 0.40^{\mathrm{a}}$ & $34.03 \pm 0.40$ & $20.03 \pm 0.40^{a, c}$ \\
\hline PA 600 & $22.09 \pm 1.09^{b}$ & $18.77 \pm 1.18^{c}$ & $6.21 \pm 0.85^{\mathrm{a}}$ & $35.39 \pm 2.88^{a, b}$ & $29.39 \pm 2.88$ & $17.95 \pm 0.58^{b}$ & $37.90 \pm 1.74^{\mathrm{a}, \mathrm{b}}$ & $32.90 \pm 1.74$ & $22.90 \pm 1.74^{\circ}$ \\
\hline
\end{tabular}

Results were expressed in mean \pm standard deviation

${ }^{a}$ Significant when compared to control at $p<0.05$

${ }^{\mathrm{b}}$ Significant when compared to ALO at $p<0.05$

'Significant when compared to MET at $p<0.05$

compromised as a result of overproduction of reactive species [29]. It has been reported in several studies that alloxan (a glucose analog used for diabetic models in animals) caused an increase in markers of oxidative stress in the liver, kidney, and pancreas of rats [30-32]. Also, diabetes has been reported to have a detrimental effect on the activities of endogenous antioxidant enzymes, and concentrations of antioxidant substances [33]; these effects are often attributed to uprising reactive oxygen species that further lead to organ impairment. In fact, one of the mechanisms through which alloxan pathophysiology occurs in the pancreatic $\beta$-cell is selective inhibition of thiol groups which serve as a glucose sensor for triggering glucose-induced insulin secretion [34]. Our study revealed that the methanol extract of Struchium sparganophora leaves may be a good source of exogenous antioxidants for rat tissues. The extract increased the level of reduced glutathione (a thiol antioxidant) and decreased the tissue concentration of malondialdehyde (a product of oxidized lipid). In addition, this plant may help in the process required in the reduction and/or scavenging of free radicals. The extract, either administered in combination or alone, increased the SOD and GST activities in the liver and pancreas, while it also increases catalase activities in the liver and kidney. Some therapeutically promising antidiabetic medicinal plants and plant products have been documented with similar antioxidant efficacy [35-38].

\section{Conclusion}

The methanol extract of Struchium sparganophora leaves (SPA) exhibited worthy antihyperglycemic, antidyslipidemic, and antioxidant efficacies when administered alone or in combination with metformin in alloxan diabetic rats. These effects are achieved by the extract through its ability to moderate dyslipidemic events, and reduce markers of oxidative stress in alloxan-induced diabetic rats.

\section{Abbreviations}

ALO: Alloxan; Al: Atherogenic index; CAT: Catalase; Cl: Cardiac index; FBG: Fasting blood glucose; GSH: Reduced glutathione; GST: Glutathione-stransferase; HDL-C: High-density lipoprotein cholesterol; LDL-C: Low-density lipoprotein cholesterol; MDA: Malondialdehyde; MET: Metformin; SOD: Superoxide dismutase; SPA: Methanol extract of Struchium sparganophoraTCTotal cholesterol; TP: Total protein; VLDL-C: Very-low-density lipoprotein cholesterol

\section{Acknowledgements}

We acknowledge the laboratory technologists of the Department of Biochemistry, Lead City University, Ibadan, Nigeria.

\section{Authors' contributions}

All authors have read and approved the submission of this manuscript. AMA designed and organized the project, FOA monitored the laboratory works and was involved in the internal review of the manuscript, OMO was involved in the writing and internal review of the manuscript, BAO was involved in the bench work and funding of the research, and OAA monitored the progression and supervised the project.

Funding

Not applicable

Availability of data and materials

All data is available upon request.

Ethics approval and consent to participate

Ethical approval (reference number: LCUERB205) was obtained from Lead City University Ethical Review Board (LCU/ERB) to perform this animal research.

\section{Consent for publication}

Not applicable

\section{Competing interests}

No competing interest to declare

\section{Author details}

${ }^{1}$ Department of Biochemistry, Lead City University, Ibadan, Nigeria. ${ }^{2}$ Department of Biochemistry, College of Biosciences, Federal University of Agriculture, Abeokuta, Nigeria. ${ }^{3}$ Department of Biochemistry, KolaDaisi University, Ibadan, Nigeria.

Received: 29 September 2019 Accepted: 12 August 2020

Published online: 16 September 2020

\section{References}

1. American Diabetes Association (2010) Diagnosis and classification of diabetes mellitus. Diabetes Care 33:S62-S69 
2. Adedapo AD, Adedeji WA, Adeosun AM, Olaremi J, Okunlola CK (2016) Antihypertensive drug use and blood pressure control among in-patients with hypertension in a Nigerian tertiary healthcare centre. International Journal of Basic \& Clinical Pharmacology 5(3):696-701

3. Akah PA, Ekekwe RR (1995) Ethnopharmacology of some Asteraceae family used in Nigeria traditional medicine. Fitoterapia. 66:4

4. Burkill HM (1994) The useful plants of west tropical Africa. In: Volume 2: Families El. Gardens, Royal Botanic

5. Jakupovic J, Zdero C, Boeker R, Warning U, Bohlmann F, Jones SB (1987) Cernocistifolide und andere sesquiterpinlactone aus Vernonia und verwandten Arten. Liesbigs Ann. Chem. 1:111-123

6. Madureira M, Ana PMPA, Gomes M, Paiva J, Cunha APD, Rosario V (2002) Antimalaria plants used in traditional medicine in Sao Tome and Principe islands. J Ethnopharmacol 81:23-29

7. Oboh G (2006) Nutritive value, antioxidant and antimicrobial properties of Struchium sparganophora leaves. J Med Food 9(2):276-280

8. Oboh G, Raddatz H, Henle T (2008) Antioxidant properties of polar and nonpolar extracts of some tropical green leafy vegetables. J Sci Food Agric 88(14):2486-2492

9. Oboh G, Akinyemi AJ, Ademiluyi AO (2012) Antioxidant properties and inhibitory effect of ethanolic extract of struchium sparganophora (ewuro odo) leaf on a - amylase and a - glucosidase activities. Afr J Tradit Complement Altern Med 9(3):342-349

10. British pharmacopoeia. (2009) Medicinal plant and pharmaceutical substances: metformin hydrochloride, Vol. I \& II, pp. 3813-3816.

11. Reitman Y, Frankel S (1957) Practical biochemistry in clinical medicine. Am J Clin Path 25:56

12. Englehardt A (1970) Measurement of alkaline phosphatase. Aerztl Labor 16: 42-43

13. Fossati P (1982) Prencipe L. Serum triglycerides determined colorimetrically with an enzyme that produces hydrogen peroxide Clin Chem 28:2077-2080

14. Lopez-Virella MF, Stone P, Ellis S, Colwell JA (1977) Cholesterol determination in high-density lipoproteins separated by three different methods. Clin Chem 23(5):882-884

15. Zollner N, Kirsch K (1962) Determination of the total lipid concentration in serum. Zentralblatt für Gesamte Experimental Medizin 135:545-549

16. Friedewald WT, Levy Rl, Fredrickson DS (1972) Estimation of the concentration of low-density lipoprotein cholesterol in plasma, without the use of the preparative ultracentrifuge. Clinical chemistry. 18(6):499-502

17. Lowry OH, Rosenbrough NJ, Farr AL, Randall RJ (1951) Protein measurement with the Folin phenol reagent. J Biol Chem 193:265-275

18. Ohkawa H, Ohishi N, Yagi K (1979) Assay for lipid peroxides in animal tissues by the thiobarbituric acid reaction. Analytical biochemistry 95(2):351-358

19. Ellman $G L$ (1959) Tissue sulfhydryl groups. Arch. Biochem. Biophys 82:70-77

20. Habig WH, Pabst MJ, Jokoby WB (1974) Glutathione transferase: a first enzymatic step in mercapturic acid III formation. J Biol Chem 249:71307139

21. Beyer WE, Fridovich I (1987) Assaying for superoxide dismutase activity: some large consequences of minor changes in conditions. Anal Biochem 161:559-566

22. Beers RF, Sizer JW (1952) Spectrophotometric method for measuring the breakdown of hydrogen peroxide catalase. J Biol Chem 195:133-140

23. Jenkins DJA, Kendall CWC, Marchie A, Jenkins AL, Augustin LSA, Ludwig DS, Barnard N, Anderson JW (2003) Type 2 diabetes and the vegetarian diet. Am J Clin Nutr 78:610S-616S

24. Phillips F, Hackett A, Billington D, Stratton G (2004) Effects of changing from a mixed to self selected vegetarian diet on anthropometric measurements in UK adults. J Hum Nutr Diet 17:249-255

25. Akinloye OA, Solanke OO (2011) Evaluation of hypolipidemic and potential antioxidant effects of Pigeon pea (Cajanus cajan (I) mill sp.) leaves in alloxan-induced hyperglycemic rats. Journal of Medicinal Plants Research 5(12):2521-2524

26. Syiem D, Warjri $P$ (2011) Hypoglycemic and antihyperglycemic effects of aqueous extract of ixeris gracilis dc. On normal and alloxan-induced diabetic mice. Diabetologia Croatica 40(3):89-95

27. Ighodaro OM, Akinloye OA, Ugbaja RN, Omotainse SO (2017) Sapium ellipticum (Hochst.) pax ethanol leaf extract maintains lipid homeostasis in streptozotocin-induced diabetic rats. International Scholarly Research Notices 1-7.

28. Mollica A, Zengin G, Locatelli M, Stefanucci A, Mocan A, Macedonio G, Carradori S, Onaolapo O, Onaolapo A, Adegoke J, Olaniyan M, Aktumsek A,
Novellino E (2017) Anti-diabetic and anti-hyperlipidemic properties of Capparis spinosa L.: in vivo and in vitro evaluation of its nutraceutical potential. Journal of Functional Foods 35:32-42

29. Ighodaro O, Akinloye O (2018) First line defense antioxidants-superoxide dismutase (SOD), catalase (CAT) and glutathione peroxidase (GPX): their fundamental role in the entire antioxidant defense grid. Alexandria journal of medicine 54(4):287-293

30. Abdullah KM, Abul Qais F, Hasan H, Naseem I (2019) Anti-diabetic study of vitamin B6 on hyperglycaemia induced protein carbonylation, DNA damage and ROS production in alloxan induced diabetic rats. Toxicology research 8(4):568-579

31. Ulla A, Alam MA, Rahman M, Isha Olive Khan DM, Sikder B, Islam M, Rahman T, Rahman N, Reza HM, Jain P, Subhan N (2019) Supplementation of Citrus maxima fruits peel powder improves glucose intolerance and prevents oxidative stress in liver of alloxan-induced diabetic rats. Mediterranean Journal of Nutrition and Metabolism 12(1):33-44

32. Robertson RP, Harmon JS (2006) Diabetes, glucose toxicity, and oxidative stress: a case of double jeopardy for the pancreatic islet $\beta$ cell. Free Radical Biology and Medicine 41(2):177-184

33. Jia G, Whaley-Connell A, Sowers JR (2018) Diabetic cardiomyopathy: a hyperglycemia-and insulin-resistance-induced heart disease. Diabetologia 61(1):21-28

34. Lenzen S, Pantem U (1988) Signal recognition by pancreatic $\beta$-cells. Biochem Pharmacol 37:371-378

35. Abdel-Salam A, Ismail M, Farahna M, Mousa H (2018) Protective effects of whey protein mixed with Garcinia kola and olive leaves extract against alloxan-induced oxidative stress and diabetes in rats. Bulletin of the National Research Centre 42(1):13

36. Ahmad B, Rehman MU, Amin I, Ahmad SB, Farooq A, Muzamil S, Hussain I, Masoodi M, Fatima B (2018) Zingerone (4-(4-hydroxy-3-methylphenyl) butan-2-one) protects against alloxan-induced diabetes via alleviation of oxidative stress and inflammation: probable role of NF-kB activation. Saudi pharmaceutical journal. 26(8):1137-1145

37. Coskun O, Kanter M, Korkmaz A, Oter S (2005) Quercetin, a flavonoid antioxidant, prevents and protects streptozotocin-induced oxidative stress and $\beta$-cell damage in rat pancreas. Pharmacological research 51(2):117-123

38. Sabu M, Smitha K, Kuttan R (2002) Anti-diabetic activity of green tea polyphenols and their role in reducing oxidative stress in experimental diabetes. Journal of ethnopharmacology 83(1-2):109-116

\section{Publisher's Note}

Springer Nature remains neutral with regard to jurisdictional claims in published maps and institutional affiliations.

\section{Submit your manuscript to a SpringerOpen ${ }^{\circ}$ journal and benefit from:}

- Convenient online submission

- Rigorous peer review

- Open access: articles freely available online

High visibility within the field

- Retaining the copyright to your article

Submit your next manuscript at $>$ springeropen.com 